\title{
Spatial and Temporal Variation of Fish Assemblages in Seti Gandaki River, Tanahu, Nepal
}

\author{
ARCHANA PRASAD*1, ANJANA SHRESTHA ${ }^{1}$, JASH HANG LIMBU $^{2} \&$ DEEP SWAR $^{3}$ \\ ${ }^{1}$ Central Department of Zoology, Tribhuvan University, Kirtipur, Kathmandu, Nepal; ${ }^{2}$ D.A.V College, Faculty \\ of Science and Humanities, Tribhuvan University, Dohighat Lalipur, Nepal; ${ }^{3}$ Nepal Fisheries Society Balaju, \\ Machhapokhari Kathmandu, Nepal. \\ *Corresponding author: archanaprasad001@gmail.com \\ Received: 25 January $2020 \quad$ Accepted: 3 November $2020 \quad$ Published: 31 December 2020
}

\begin{abstract}
The space and time variations of the fish community structure in hill streams of Nepal are poorly understood. This research aims at studying the space and time variation of fish community structure in the Seti Gandaki River, Tanahu, Nepal. The field survey was conducted from July 2017 to June 2018 and the fishes were sampled from six sites using a medium size cast net of mesh size ranging from $3 \mathrm{~mm}$ to $6 \mathrm{~mm}$ mesh size, 25-33 feet length and 3.5-5 feet width, with the help of local fisher man. A total of 1,440 individuals were caught representing 46 species belonging to three order, nine families and 23 genera. The analysis of similarity (ANOSIM) showed significant difference in space $(R=0.824, P$ $=0.001)$ but not in time $(R=0.135, P=0.021)$. On the basis of similarity percentage (SIMPER) analysis, $85.43 \%$ similarity was found among the seasons and major contributing species were Barilius bendelisis $(8.44 \%)$ followed by $B$. vagra (7.79\%), Tor putitora (7.27\%), Garra gotyla (7\%), Acanthocobotis botia (6.7\%), Neolissochilus hexagonolepis (6.64\%), Barilius shacra (6\%), B. barila (4.5\%) and Opsarius barna (4.37\%). On the other hand, $85.24 \%$ similarity was found among the sites and major contributing species were B. bendelisis (8.8\%) followed by B. vagra (7.6\%), G. gotyla (7.27\%), T. putitora (7.17\%), A. botia (6.97\%), N. hexagonolepis $(6.7 \%)$, B. shacra $(6.34 \%)$, B. barila $(4.7 \%)$ and $O$. barna $(4.39 \%)$. Results from the Canonical Correspondence Analysis indicated that the environmental variables, such as $\mathrm{pH}$, total hardness, alkalinity, dissolved oxygen and water temperature have shown to determine the fish community structure of Seti Gandaki River.
\end{abstract}

Keywords: Fish diversity, freshwater, habitat, spatio-temporal, stream

Copyright : This is an open access article distributed under the terms of the CC-BY-NC-SA (Creative Commons Attribution-NonCommercial-ShareAlike 4.0 Internationa License) which permits unrestricted use, distribution, and reproduction in any medium, for non-commercial purposes, provided the original work of the author(s) is properly cited.

\section{INTRODUCTION}

The physical-chemical environmental parameter influences the fish community structure, which are spatially different and temporally diverse, and biotic interactions such as competition and predation (Gorman, 1988; Harvey \& Stewart, 1991; Grossman et al., 1998). Habitat variables such as water temperature, depth (Kadye et al., 2008), water velocity (Yu \& Lee, 2002; Limbu \& Prasad, 2020), stream width (Gerhard et al., 2004), substrate, altitude, conductivity (Yu \& Lee, 2002; Kadye et al., 2008), dissolved oxygen, $\mathrm{pH}$, freecarbon dioxide (Limbu et al., 2019b) and climate (Magalhaes et al., 2002) have all been shown to affect fish community. However, changing environmental parameters can affect biotic communities in multiple ways and function of ecosystems (McGill et al., 2006; Conversi et al., 2015). Environmental variables are reported to shape the spatial distribution of species (Perry et al., 2005) and influence the temporal variation of communities (Rouyer et al., 2008).

The space and time variations of the fish community structure in the rivers and streams of Nepal are poorly understood (Limbu $\&$ Gupta, 2019). Some related studies done in the Nepal's rivers include Edds (1986), Shrestha et al. (2009), Shah (2016), Shrestha (2016). Subba et al., (2017), Limbu et al. (2018b; 2019a; $2019 b)$. However, these studies did not mention, which factors (physio-chemical factors, current velocity, substrate composition, stream width, water 
temperature, water volume, etc.) contribute most to fish community variations. Some aspects of the fisheries and fish ecological studies such as their diversity, space and time distribution and abundance in rivers of Nepal are needed (Mishra \& Baniya, 2016). To better monitor, manage and conserve, and to know their status of the fisheries, there is an urgent need to update the information on the spatial and temporal fish diversity, community structure and distribution patterns (Ngor et al., 2018). Therefore, the present study was conducted to determine spatial and temporal variation of fish assemblages with environmental correlates in Seti Gandaki River, Tanahu, Nepal.

\section{MATERIALS AND METHODS}

\section{Study Area}

The present study area, the Seti Gandaki River is situated in Western Nepal, which rises from the base of the Annapurna massif and surges through south and south-east part of Pokhara and Damauli which finally joins with Trisuli River near Devghat.

To study fish and environmental parameters, six sampling sites of A, B, C, D, E and F (Figure 1) were allocated along the sampling stretch of the Seti Gandaki River. The sampling site A was selected at upstream of Bhimad Bazar (Changthandi confluence to $2 \mathrm{~km}$ upstream). The second sampling site B was chosen near confluence spot of Seti and Jidi Khola (downstream at Bhimad Bazar). The third sampling site $\mathrm{C}$ was selected at confluence spot of Seti and Phedi Khola. The sampling site D was selected at dam site of Seti Gandaki River. The sampling site $\mathrm{E}$ and site $\mathrm{F}$ were chosen at confluence spot of Seti and Madi Khola and downstream of proposed powerhouse in Seti River (Table 1).

\section{Sampling}

Sampling was conducted four times a year covering all seasons (winter in January, spring in April, summer in June and autumn in October) over one year of 2018. In this study, each sampling site was 200-250 m long and fish agglomeration was done approximately 2 hours by cast net at each sampling site. The fishes were sampled using cast net of mesh size ranging from $3 \mathrm{~mm}$ to $6 \mathrm{~mm}$ mesh size, 25-33 feet length and 3.5-5 feet width, with the help of local fisherman. Before preservation, collected fishes were photographed with Nikon Digital Camera (D5600, DX, 24.2 megapixels, Japan). After photography, about $10 \%$ collected fishes were
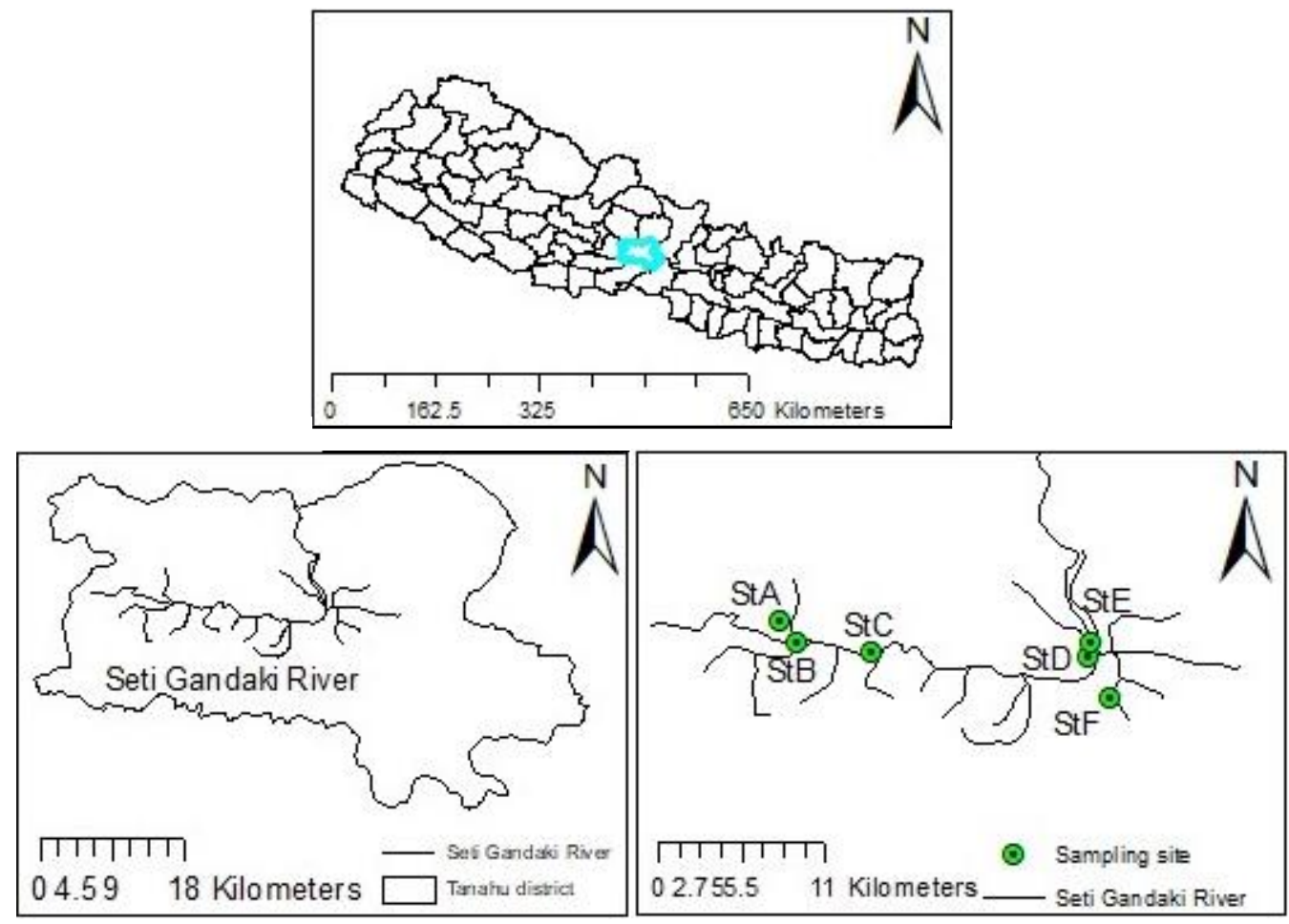

Figure 1. Sampling sites in Seti Gandaki River 
Table 1. Information of different stations

\begin{tabular}{|c|c|c|c|}
\hline Sites & Sampling spot & Location & GPS Location \\
\hline A & Before Reservoir in Seti river & Myagde and Bhimad, Tanahun & 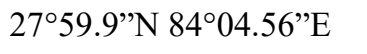 \\
\hline $\mathrm{B}$ & Confluence of Seti and Jidi khola & Bhimad, Tanahun & $27^{\circ} 58.26^{\prime} \mathrm{N} 84^{\circ} 5.34 ” \mathrm{E}$ \\
\hline $\mathrm{C}$ & Confluence of Seti and Phedi khola & Bhimad, Tanahun & $27^{\circ} 58.3^{\prime \prime} \mathrm{N} 84^{\circ} 8.10^{\prime \prime} \mathrm{E}$ \\
\hline $\mathrm{D}$ & Proposed Dam site in Seti River & Patan, Damauli & $27^{\circ} 57.52^{\prime \prime} \mathrm{N} 84^{\circ} 15.54^{\prime \prime} \mathrm{E}$ \\
\hline $\mathrm{E}$ & Confluence of Seti and Madi & Byas & $27^{\circ} 58.25^{\prime}{ }^{\prime} \mathrm{N} 84^{\circ} 15.57^{\prime \prime} \mathrm{E}$ \\
\hline $\mathrm{F}$ & $\begin{array}{l}\text { Downstream of proposed Power house in } \\
\text { Seti river }\end{array}$ & Damauli & $27^{\circ} 56.25^{\prime \prime} \mathrm{N} 84^{\circ} 16.40^{\prime \prime} \mathrm{E}$ \\
\hline
\end{tabular}

preserved in $10 \%$ formaldehyde solution in plastic jar by making their head upside for the protection of their caudal fin and remaining samples were returned to their own natural habitat from where they were captured. Afterwards, preserved specimens were taken to the laboratory of the Central Department of Zoology (CDZ), Tribhuvan University, Institute of Science and Technology, Kirtipur, Kathmandu, Nepal. The identification was carried out with the help of standard taxonomic references (Talwar \& Jhingran, 1991; Jayaram, 2010).

The following environmental variables were analyzed during each field visit: water temperature, dissolved oxygen (DO), $\mathrm{pH}$, hardness, and alkalinity. Water temperature $\left({ }^{\circ} \mathrm{C}\right)$ was measured with a digital thermometer (Hanna, HI98501, UK) by placing it in the water at a depth of one feet. The DO $(\mathrm{mg} / \mathrm{l})$ was measured by the Winkler titrametric method, while $\mathrm{pH}$ was measured using a $\mathrm{pH}$ meter (HI98107, Hanna Instrument, UK). Total hardness (mg/l) was determined using EDTA titrametric method. To determine alkalinity water sample of $10 \mathrm{ml}$ was taken in a conical flask and one drop of phenolphthalein was added to it and mixed well. Bromocresol Green-methyl Red (1 packet) was added to it and stirred properly. It was then titrated with sulfuric acid and end point was recorded.

\section{Data Analysis}

The Shannon-Weiner diversity (Shannon \& Weaver, 1963) was calculated by the following Eq. (1):
$\mathrm{H}=\sum_{i=1}^{S} P i * \log P i$

Where $\mathrm{S}$ is the total number of species and $P i$ is the relative cover of $i_{t h}$ of species.

Margalef index (d) (Margalef, 1968) was used to measure species richness by using the following Eq. (2):

$d=(\mathrm{S} / 1)=\log (N)$

where $\mathrm{S}$ is the total species and $N$ is total individuals.

The dominance index (Harper, 1999) was calculated by using the following Eq. (3):

$\mathrm{D}=\sum_{i}\left(\frac{n i}{n}\right)^{2}$

Where $n_{i}$ is number of individuals of species $i$.

One-way analysis of similarities (ANOSIM) (Clarke, 1993) was used to test the significant difference among the space and time scales. To visualize the major contributing species both to space and time, similarity percentage (SIMPER) analysis was performed (Clarke, 1993). The correlation between fish community structure and environmental variables were first done using Detrended correspondence analysis (DCA). The axis length $(\geq 2.5)$ and eigen value $(\geq 0.5)$ acquired from DCA suggested that the linear model of Canonical Correspondence Analysis (CCA) was more applicable. Therefore, a direct multivariate ordination method (Ter Braak, 1986) based on a linear response of species to environmental 
gradients was applied by using vegan library in $\mathrm{R}$ (Oksanen, 2015).

\section{RESULTS AND DISCUSSION}

A total of 1,440 fish individuals were collected in the Seti Gandaki River, representing 46 fish species belonging to four orders, nine families and 23 genera (Table 2 and 3). Among the four orders, Cypriniformes was found to be the most dominating order with 33 species $(71.7 \%)$, followed by Siluriformes with 10 species $(21.7 \%)$, Perciformes with two species $(4.34 \%)$ and Synbranchiformes with a single species $(2.17 \%)$. Gautam et al. (2016) and Pokharel (2011) also reported that Cypriniformes as the dominant order in terms of both species composition, and individuals captured. Besides that, Jha (2006) reported 18 fish species, environment impact assessment of Upper Seti Hydropower Project (Nepal Electricity Authority/ Tanahu Hydropower Limited, 2012) reported 36 fish species, and Pokharel et al. (2018) reported 30 fish species, belonging to five orders, nine families and 24 genera from Seti Gandaki River.

The diversity in terms of number (46 species) observed in the present study was 16 species greater than Pokharel et al. (2018). It might be due to the limited study areas covered in the earlier report. Cypriniformes and Cyprinidae were the most abundant and species rich order and family, respectively. This is in consistent with the findings of previous studies reported from different rivers and streams of Nepal. For example, Shrestha et al. (2009), Shrestha (2016), Mishra and Baniya (2016), Subba et al. (2017), Limbu et al. (2018a), Limbu et al. (2019a, 2019b), and Limbu and Prasad (2020) from Tamor, Triyuga, Dewmai, Melamchi, Morang district, Damak, Ratuwa, Eastern Nepal and Nuwa River. Nelson (2007) also indicated that the majority of the fishes from the river fall under the order Cypriniformes, the huge order of freshwater fishes, which includes 2,422 species.

In terms of temporal variation of fish assemblages, fish species Chagunius chagunio, Neolissochilus hexagonolepis, Tor putitora, Puntius sophore, Barilius barna, Barilius shacra, Garra gotyla, Acanthocobitis botia and Nemacheilus corica were recorded from all four seasons (Table 2). The present finding is in consistent with previous studies (Limbu et al., 2018b; Limbu et al., 2019a; 2019b). Species like Glyptothorax indicus and Nangra viridescens were recorded from summer only. The highest individuals were recorded in summer and lowest in spring.

In terms of spatial variation (Table 3), exotic fish, Oreochromis niloticus was recorded from site $\mathrm{C}$ and site E. According to the local fishermen, this fish was introduced in different lakes of Pokhara Valley (Fewa Lake and Begnas Lake) and have escaped from there and were found in river. Thapa (2018) also reported that $25.13 \%$ of $O$. niloticus in Diplang Lake. It is due to high tolerance capacity of this fish in adverse water quality conditions (Rao, 2017). According to local fishermen, there are large sized Anguilla bengalensis in the river, but during study it was not recorded. It may be due to decline in their number or obstruction in their regular migrating pathways due to constructions of different barriers (hydro dams) in the river.

The ANOSIM showed significance difference in space $(R=0.824, p=0.001)$, but not in time $(R=$ $0.135, p=0.021)$, which is similar to the findings of Yan et al. (2010). According to SIMPER analysis, $85.43 \%$ similarity was found among the months with major contributing species, Barilius bendelisis (8.44\%), Barilius vagra (7.79\%), T. putitora (7.27\%), G. gotyla (7\%), A. botia (6.7\%), N. hexagonolepis (6.64\%), B. shacra (6\%), B. barila (4.5\%) and Opsarius barna (4.37\%). An $85.24 \%$ similarity was found among the sites with major contributing species, B. bendelisis (8.8\%), followed by B. vagra (7.6\%), G. gotyla (7.27\%), T. putitora $(7.17 \%), \quad A$. botia $(6.97 \%), \quad N$. hexagonolepis (6.93\%), B. shacra (6.34\%), B. barila $(4.61 \%)$ and O. barna (4.39\%) (Table 4).

\section{Species Diversity}

The Shannon-Weiner diversity index of temporal variation ranged in between 1.17 to 1.83 . The highest diversity index was recorded during autumn and lowest in winter (Figure 2). In term of spatial variation of diversity index, highest diversity index was found to be at site $\mathrm{C}$ and lowest at site $\mathrm{D}$ (Figure 3 ). The evenness index was reported highest in autumn and lowest in winter (Figure 2), whereas highest evenness index was found to be at site D and lowest at site E (Figure 3). There is no significant difference $(p<0.05)$ observed for temporal and spatial variation. The highest value of species richness was found in winter and lowest value was found in summer and spring respectively (Figure 2), whereas the highest richness value was reported from site $\mathrm{D}$ and lowest value was recorded at site $\mathrm{A}$ (Figure 3). 
Table 2. Temporal variation of fish assemblages of Seti Gandaki River

\begin{tabular}{|c|c|c|c|c|c|c|c|}
\hline Family & Species & Code & Summer & Autumn & Winter & Spring & $\begin{array}{c}\text { Total } \\
\text { individuals }\end{array}$ \\
\hline Cyprinidae & Chagunius chagunio & $\mathrm{C} 1$ & + & + & + & + & 30 \\
\hline Cyprinidae & Neolissochilus hexagonolepis & $\mathrm{C} 2$ & + & + & + & + & 119 \\
\hline Cyprinidae & Tor putitora & $\mathrm{C} 3$ & + & + & + & + & 110 \\
\hline Cyprinidae & Tor tor & $\mathrm{C} 4$ & + & + & - & + & 31 \\
\hline Cyprinidae & Puntius conchonius & $\mathrm{C} 5$ & + & + & - & - & 14 \\
\hline Cyprinidae & Puntius guganio & C6 & - & + & - & - & 1 \\
\hline Cyprinidae & Puntius sophore & $\mathrm{C} 7$ & + & + & + & + & 31 \\
\hline Cyprinidae & Puntius terio & $\mathrm{C} 8$ & + & + & + & - & 19 \\
\hline Cyprinidae & Puntius ticto & C9 & + & - & - & - & 32 \\
\hline Cyprinidae & Labeo dyocheilus & $\mathrm{C} 10$ & + & + & - & - & 3 \\
\hline Cyprinidae & Labeo dero & $\mathrm{C} 11$ & + & + & + & - & 25 \\
\hline Cyprinidae & Labeo pangusia & $\mathrm{C} 12$ & + & + & - & + & 6 \\
\hline Cyprinidae & Aspidoparia morar & $\mathrm{C} 13$ & + & - & + & + & 18 \\
\hline Cyprinidae & Barilius barila & $\mathrm{C} 14$ & + & + & - & + & 61 \\
\hline Cyprinidae & Opsarius barna & $\mathrm{C} 15$ & + & + & + & + & 59 \\
\hline Cyprinidae & Barilius bendelesis & $\mathrm{C} 16$ & + & + & + & + & 137 \\
\hline Cyprinidae & Barilius radiolatus & $\mathrm{C} 17$ & + & + & - & - & 12 \\
\hline Cyprinidae & Barilius shacra & $\mathrm{C} 18$ & + & + & + & + & 79 \\
\hline Cyprinidae & Barilius vagra & $\mathrm{C} 19$ & + & - & + & + & 127 \\
\hline Cyprinidae & Brachydanio rerio & $\mathrm{C} 20$ & - & + & - & - & 1 \\
\hline Cyprinidae & Esomus danricus & $\mathrm{C} 21$ & - & + & - & - & 2 \\
\hline Cyprinidae & Crossocheilus latius & $\mathrm{C} 22$ & + & - & + & + & 7 \\
\hline Cyprinidae & Garra annandalei & $\mathrm{C} 23$ & + & + & + & - & 26 \\
\hline Cyprinidae & Garra gotyla & $\mathrm{C} 24$ & + & + & + & + & 108 \\
\hline Cyprinidae & Garra lamta & $\mathrm{C} 25$ & + & + & - & - & 29 \\
\hline Cyprinidae & Garra mullya & $\mathrm{C} 26$ & + & + & - & - & 14 \\
\hline Balitoridae & Acanthocobitis botia & $\mathrm{C} 27$ & + & + & + & + & 120 \\
\hline Cobitidae & Nemacheilus corica & $\mathrm{C} 28$ & + & + & + & + & 22 \\
\hline Cobitidae & Schistura multifasciata & $\mathrm{C} 29$ & - & + & - & - & 2 \\
\hline Cobitidae & Schistura savona & $\mathrm{C} 30$ & - & + & - & - & 3 \\
\hline Cobitidae & Botia almorhae & $\mathrm{C} 31$ & + & + & - & - & 10 \\
\hline Cobitidae & Botia geto & $\mathrm{C} 32$ & - & + & - & + & 9 \\
\hline Cobitidae & Botia lohachata & $\mathrm{C} 33$ & - & - & - & + & 4 \\
\hline Bagaridae & Mystus bleekeri & $\mathrm{C} 34$ & - & + & - & + & 3 \\
\hline Schilbeidae & Clupisoma garua & $\mathrm{C} 35$ & + & + & + & - & 16 \\
\hline Schilbeidae & Clupisoma montana & $\mathrm{C} 36$ & - & - & - & + & 2 \\
\hline Sisoridae & Bagarius yarrelli & $\mathrm{C} 37$ & - & - & + & - & 1 \\
\hline Sisoridae & Glyptothorax alaknandi & $\mathrm{C} 38$ & + & - & - & + & 19 \\
\hline Sisoridae & Glyptothorax cavia & C39 & + & + & - & - & 2 \\
\hline
\end{tabular}


Table 2. Continue...

\begin{tabular}{|c|c|c|c|c|c|c|c|}
\hline Family & Species & Code & Summer & Autumn & Winter & Spring & $\begin{array}{c}\text { Total } \\
\text { individuals }\end{array}$ \\
\hline Sisoridae & Glyptothorax indicus & $\mathrm{C} 40$ & + & - & - & - & 1 \\
\hline Sisoridae & Glyptothorax telchitta & $\mathrm{C} 41$ & + & - & - & + & 11 \\
\hline Sisoridae & Nangra viridescens & $\mathrm{C} 42$ & + & - & - & - & 2 \\
\hline Sisoridaae & Pseudecheneis sulcatus & $\mathrm{C} 43$ & - & + & - & + & 9 \\
\hline Mastacembelidae & Mastacembelus armatus & $\mathrm{C} 44$ & + & + & - & + & 7 \\
\hline Cichlidae & Oreochromis niloticus & $\mathrm{C} 45$ & + & + & - & - & 76 \\
\hline \multirow[t]{2}{*}{ Channidae } & Channa orientalis & $\mathrm{C} 46$ & + & + & - & - & 20 \\
\hline & Total & & 415 & 338 & 374 & 313 & 1,440 \\
\hline
\end{tabular}

Table 3. Spatial variation of fish assemblages of Seti Gandaki River

\begin{tabular}{|c|c|c|c|c|c|c|c|c|}
\hline \multirow{2}{*}{ Family } & \multirow{2}{*}{ Species } & \multicolumn{6}{|c|}{ Sites } & \multirow{2}{*}{$\begin{array}{c}\text { Total } \\
\text { individuals }\end{array}$} \\
\hline & & $\mathbf{A}$ & B & $\mathrm{C}$ & D & $\mathbf{E}$ & $\mathbf{F}$ & \\
\hline Cyprinidae & Chagunius chagunio & - & + & - & + & + & + & 30 \\
\hline Cyprinidae & Neolissochilus hexagonolepis & + & + & + & - & + & + & 119 \\
\hline Cyprinidae & Tor putitora & + & + & + & + & + & + & 110 \\
\hline Cyprinidae & Tor tor & + & - & + & + & - & + & 31 \\
\hline Cyprinidae & Puntius conchonius & + & - & + & - & - & - & 14 \\
\hline Cyprinidae & Puntius guganio & - & - & + & - & - & - & 1 \\
\hline Cyprinidae & Puntius sophore & + & + & + & - & - & - & 31 \\
\hline Cyprinidae & Puntius terio & + & - & - & - & + & - & 19 \\
\hline Cyprinidae & Puntius ticto & - & - & + & - & + & - & 32 \\
\hline Cyprinidae & Labeo dyocheilus & - & + & - & + & - & + & 3 \\
\hline Cyprinidae & Labeo dero & - & + & - & + & + & + & 25 \\
\hline Cyprinidae & Labeo pangusia & - & + & - & + & + & - & 6 \\
\hline Cyprinidae & Aspidoparia morar & + & + & - & + & - & - & 18 \\
\hline Cyprinidae & Barilius barila & + & + & + & + & + & + & 61 \\
\hline Cyprinidae & Barilius barna & + & + & + & + & + & + & 59 \\
\hline Cyprinidae & Barilius bendelesis & + & + & + & + & + & + & 137 \\
\hline Cyprinidae & Barilius radiolatus & - & - & + & - & - & - & 12 \\
\hline Cyprinidae & Barilius shacra & + & + & + & - & + & + & 79 \\
\hline Cyprinidae & Barilius vagra & + & + & + & + & - & + & 127 \\
\hline Cyprinidae & Brachydanio rerio & - & + & - & - & - & - & 1 \\
\hline Cyprinidae & Esomus danricus & - & - & + & - & - & - & 2 \\
\hline Cyprinidae & Crossocheilus latius & - & + & - & - & + & + & 7 \\
\hline Cyprinidae & Garra annandalei & + & + & + & - & - & + & 26 \\
\hline Cyprinidae & Garra gotyla & + & + & + & + & + & + & 108 \\
\hline
\end{tabular}


Table 3. Continue...

\begin{tabular}{|c|c|c|c|c|c|c|c|c|}
\hline \multirow{2}{*}{ Family } & \multirow{2}{*}{ Species } & \multicolumn{6}{|c|}{ Sites } & \multirow{2}{*}{$\begin{array}{c}\text { Total } \\
\text { individuals }\end{array}$} \\
\hline & & $\mathbf{A}$ & B & $\mathbf{C}$ & D & $\mathbf{E}$ & $\mathbf{F}$ & \\
\hline Cyprinidae & Garra lamta & + & + & - & - & - & - & 29 \\
\hline Cyprinidae & Garra mullya & - & + & - & - & + & + & 14 \\
\hline Balitoridae & Acanthocobitis botia & + & + & + & + & + & - & 120 \\
\hline Cobitidae & Nemacheilus corica & + & + & + & - & - & - & 22 \\
\hline Cobitidae & Schistura multifasciata & - & - & + & - & - & - & 2 \\
\hline Cobitidae & Schistura savona & - & - & + & - & - & - & 3 \\
\hline Cobitidae & Botia almorhae & - & - & - & - & + & + & 10 \\
\hline Cobitidae & Botia geto & - & - & + & - & + & + & 9 \\
\hline Cobitidae & Botia lohachata & - & - & - & + & + & - & 4 \\
\hline Bagaridae & Mystus bleekeri & + & - & - & - & - & - & 3 \\
\hline Schilbeidae & Clupisoma garua & - & - & + & + & - & + & 16 \\
\hline Schilbeidae & Clupisoma montana & - & - & - & - & + & + & 2 \\
\hline Sisoridae & Bagarius yarrelli & - & - & + & - & - & - & 1 \\
\hline Sisoridae & Glyptothorax alaknandi & + & + & + & - & + & + & 19 \\
\hline Sisoridae & Glyptothorax cavia & - & - & - & + & - & - & 2 \\
\hline Sisoridae & Glyptothorax garhwali & - & - & - & - & - & + & 1 \\
\hline Sisoridae & Glyptothorax indicus & - & - & + & - & + & + & 11 \\
\hline Sisoridae & Nangra viridescens & - & - & - & + & - & + & 2 \\
\hline Sisoridae & Pseudecheneis sulcatus & - & - & + & + & - & - & 9 \\
\hline Mastacembelidae & Mastacembelus armatus & - & + & + & - & + & + & 7 \\
\hline Cichlidae & Oreochromis niloticus & - & - & + & - & + & - & 76 \\
\hline \multirow[t]{2}{*}{ Channidae } & Channa orientalis & + & - & - & - & + & - & 20 \\
\hline & Total & 290 & 167 & 568 & 90 & 170 & 155 & 1,440 \\
\hline
\end{tabular}

Table 4. Average similarity and discriminating fish in each month and site using SIMPER analysis

\begin{tabular}{cccc}
\hline Month $\mathbf{( 8 5 . 4 3 \% )}$ & \multicolumn{2}{c}{ Site $\mathbf{( 8 5 . 2 4 \% )}$} \\
\hline Contributory species & $\%$ & Contributory species & $\%$ \\
\hline Barilius bendelesis & 8.39 & Barilius bendelesis & 8.72 \\
Barilius vagra & 7.69 & Barilius vagra & 7.60 \\
Tor putitora & 7.27 & Garra gotyla & 7.27 \\
Garra gotyla & 7.08 & Tor putitora & 7.17 \\
Acanthocobotis botia & 6.85 & Acanthocobitis botia & 6.97 \\
Neolissochilus hexagonolepis & 6.54 & Neolissochilus hexagonolepis & 6.93 \\
Barilius shacra & 6.08 & Barilius shacra & 6.34 \\
Barilius barila & 4.90 & Barilius barila & 4.61 \\
Opsarius barna & 4.37 & Opsarius barna & 4.39 \\
Labeo dero & 3.80 & Labeo dero & 3.59 \\
\hline
\end{tabular}


Table 4. Continue...

\begin{tabular}{cccc}
\hline Month $\mathbf{( 8 5 . 4 3 \% )}$ & \multicolumn{3}{c}{ Site $\mathbf{( 8 5 . 2 4 \% )}$} \\
\hline Contributory species & $\%$ & Contributory species & $\%$ \\
\hline Barilius radiolatus & 3.14 & Garra lamta & 2.98 \\
Garra lamta & 2.96 & Barilius radiolatus & 2.91 \\
Chagunius chagunio & 2.89 & Chagunius chagunio & 2.89 \\
Nemacheilus corica & 2.51 & Nemacheilus corica & 2.52 \\
Tor tor & 2.00 & Tor tor & 2.10 \\
Clupisoma montana & 1.92 & Clupisoma montana & 1.99 \\
Aspidoparia morar & 1.92 & Aspidoparia morar & 1.92 \\
Pseudecheneis sulcatus & 1.729 & Pseudecheneis sulcatus & 1.70 \\
Garra mullya & 1.67 & Garra mullya & 1.63 \\
Garra annandalei & 1.61 & Garra annandalei & 1.55 \\
Glyptothorax indicus & 1.56 & Puntius terio & 1.49 \\
Puntius terio & 1.51 & Glyptothorax indicus & 1.48 \\
Botia lohachata & 1.50 & Botia lohachata & 1.38 \\
Puntius conchonius & 1.24 & Puntius conchonius & 1.25 \\
\hline
\end{tabular}

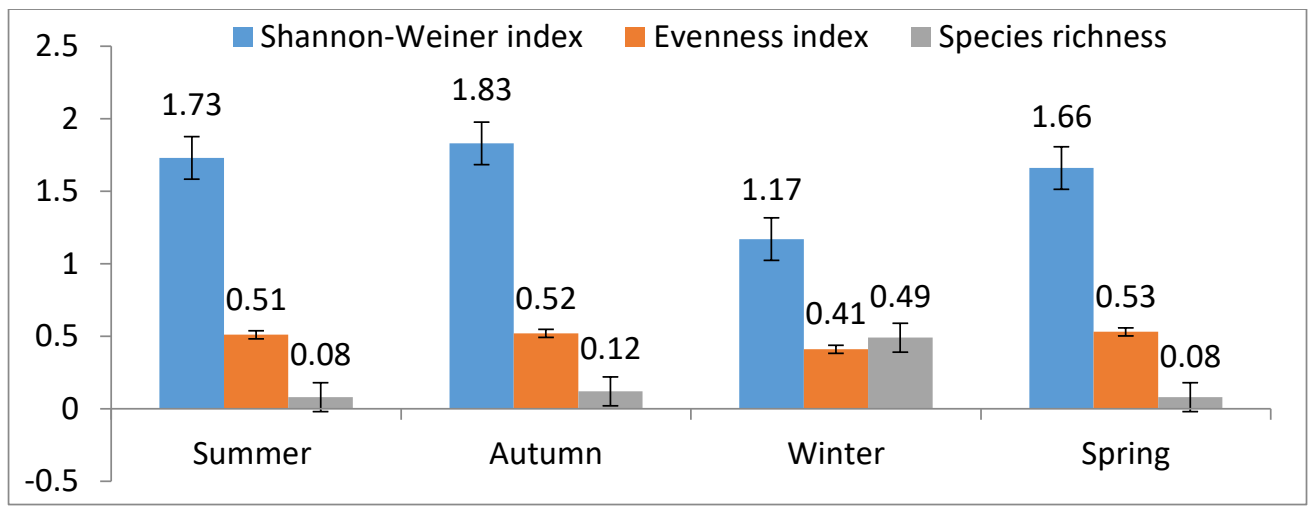

Figure 2. Temporal variation of species diversity index of Seti Gandaki River.

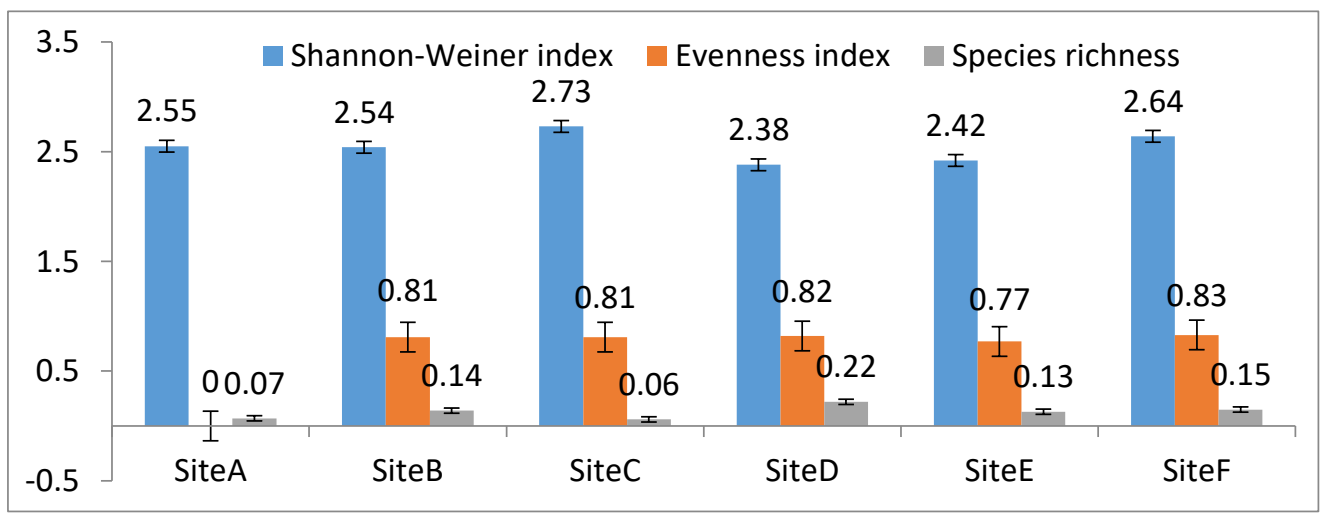

Figure 3. Spatial variation of species diversity index of Seti Gandaki River. 


\section{Canonical Correspondence Analysis}

The result obtained after the CCA was plotted in Figure 4. The first and second axis of the CCA accounted for $42 \%$ and $30 \%$, respectively. The CCA tri-plot indicated the correlation between species and environmental variables. The species of $T$. putitora (C3), Tor tor (C4), P. sophore (C7), Puntius ticto (C9), Labeo dero (C11), Aspidoparia morar (C13), B. vagra (C19), Crossocheilus latius (C22), Botia lohachata (C33), Bagarius yarrelli (C37), and G. indicus (C40) were positively related to $\mathrm{pH}$ but negatively related to hardness and DO. The fish species of Chagunius chagunio (C1), Puntius terio (C8), Garra mullya (C26), A. botia (C27), Botia geto (C32), N. viridescens (C42), O. niloticus (C45) and Channa orientalis (C46) were positively related to dissolved oxygen and hardness but negatively related to $\mathrm{pH}$.

In contrast, fish species of Puntius conchonius (C5), Labeo dyocheilus (C10), Labeo pangusia (C12), Barilius barila (C14), O. barna (C15),
Brachydanio rerio (C20), Garra lamta (C25), Clupisoma montana (C36), Glyptothorax telchitta (C41) and Mastacembelus armatus (C44) were positively related to alkalinity and water temperature. The fish species of $N$. hexagonolepis (C2), B. bendelesis (C16), Barilius radiolatus $(\mathrm{C} 17)$, B. shacra (C18), Garra annandalei (C23), G. gotyla (C24), N. corica (C28), Schistura multifasciata (C29), Schistura savona (C30), T. putitora (C3) and Glyptothorax cavia (C39) were not related to any environmental parameters.

Physical and chemical characteristics are important determinants of the situation of fish community ( $\mathrm{Li}$ et al., 2012). Results from the CCA indicated that the environmental parameters, such as $\mathrm{pH}$, total hardness, alkalinity, DO and water temperature have shown to determine the fish community structure of Seti Gandaki River. The previous studies, such as ( Yu \& Lee, 2002; Kadye et al., 2008; Mishra \& Baniya, 2016; Limbu et al., 2019a). Limbu and Prasad (2020) have also mentioned that these variables play a crucial role in shaping the fish community structure.

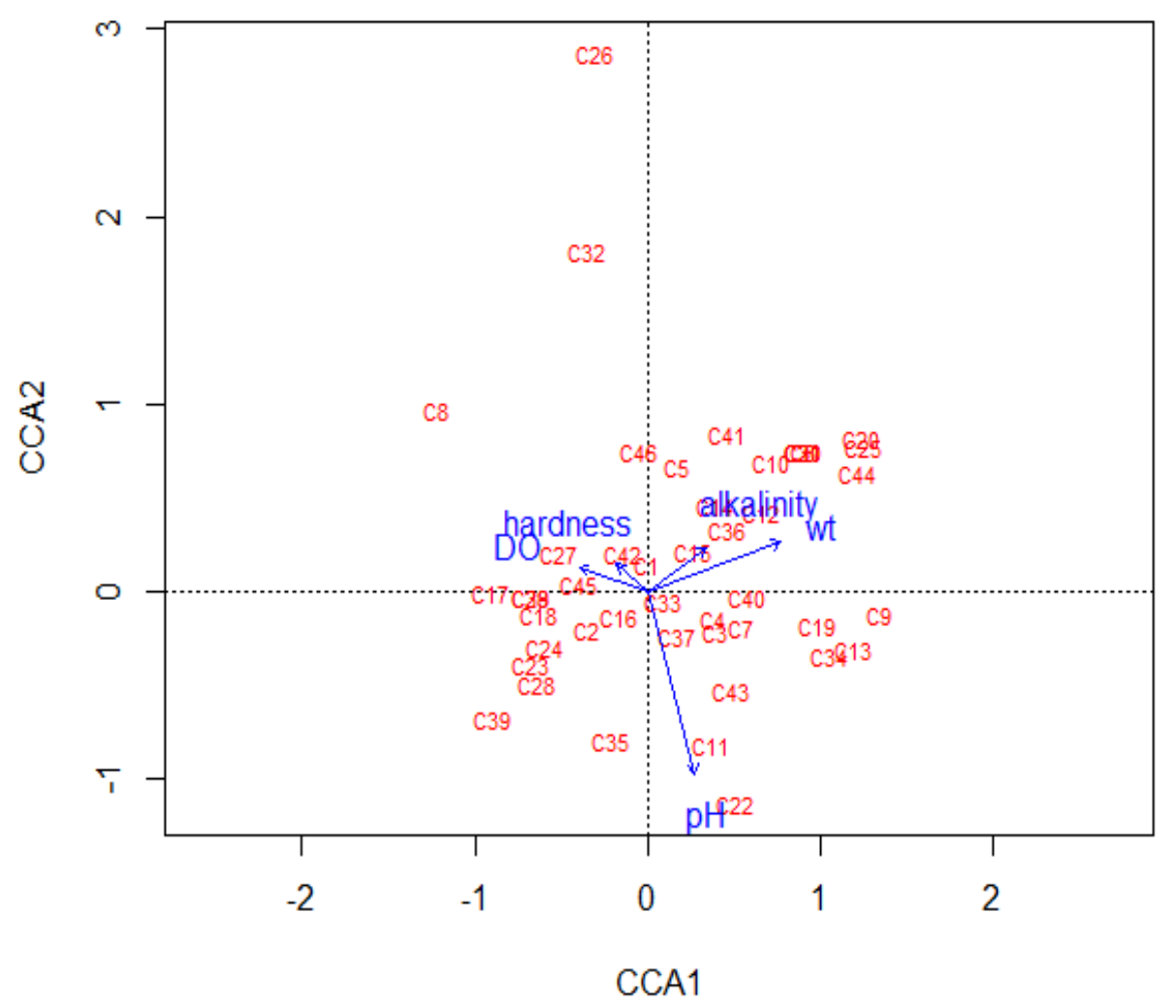

Figure 4. Canonical correspondence analysis (CCA) ordination showing fish species in relation to sites, seasons and environmental variables of Seti Gandaki River $(\mathrm{DO}=$ dissolved oxygen, $\mathrm{Wt}=$ water temperature $)$ For species code, please refer Table 1. 


\section{CONCLUSION}

In this study, 46 fish species were reported. Among them B. bendelisis, followed by B. vagra, Tor putitora, Garra gotyla, Acanthocobotis botia, Neolisochilus hexagonolepis, B. shacra, B. barila and Opsarius barna were the major contributory fish species reported from the Seti Gandaki River. Results from the Canonical Correspondence Analysis (CCA) ordination indicated that dissolved oxygen (DO), $\mathrm{pH}$, hardness, and water temperature are the pivotal environmental parameters to determine fish community structure in the Seti Gandaki River, Tanahu, Nepal. River dam constructions were found to be major threats to long (for example, Anguilla bengalensis, Bagarius spp) and short (Neolissochilus hexagonolepis) distance migratory fishes. Besides, dynamiting, extraction and transportation of boulders, cobbles, pebbles, sand mining were also found to be existing threats to the fish diversity of Seti Gandaki River. So, for the better protection and conservation of the native species including migratory fish species, habitat rehabilitation, and construction of fish ladders are necessarily needed.

\section{ACKNOWLEDGEMENTS}

We would like to thank the Advisor from Nepal Fisheries Society, Mr. Deep Bahadur Swar, and Mr. Mukunda Bahadur Thapa for valuable support and suggestions. We are very much grateful to Tahanhun Hydropower Project family for the help and support during the whole study period. Special thanks to Chandra Maya Shrestha, Indra Ghimire, Pramisha Karki, Saroj Thapa, Shankar Rijal and Pasang Sherpa for their support and suggestion during and after research work.

\section{REFERENCES}

Clarke, K.R. (1993). Nonparametric multivariate analyses of changes in community structure. Australian Journal of Ecology, 18: 11743.

Conversi, A., Dakos, V. Gårdmark, A., Ling, S., Folke, C., Mumby, J.P., Greene, C., Edwards, M., Blenckner, T., Casini, M., Pershing, A. \& Möllmann, C. (2015). A holistic view of marine regime shifts. Philosophical Transactions of the Royal Society B Biological Sciences, 370: 20130279.

Edds, D.R. (1986). Fishes of Kali Gnagaki/Narayani Rivers, Nepal. Journal of Natural History Museum, 10(14): 14-22.
Gautam, D., Jain, R., Paudel, L. \& Shrestha, M. (2016) Fish faunal diversity and species richness of tectonic Lake Rupa in the mid-hill of Central Nepal. International Journal of Fisheries and Aquatic Studies, 4(3): 690-694.

Gerhard, P., Maraes, R. \& Molander, S. (2004). Stream fish communities and their associations to habitat variables in a rain forest reserve in southeastern Brazil. Environmental Biology of Fishes, 71: 321-330.

Gorman, O.T. (1988). The dynamics of habitat use in a guild of Ozark minnows. Ecological Monograph, 58(1): 1-18.

Grossman, G.D., Ratajczak, R.E., Crawford, M. \& Freeman, M.C. (1998). Assemblage organization in stream fishes: effects of environmental variation and interspecific interactions. Ecological Monograph, 68(3): 395-420.

Harper, D.A.T. (1999). Numerical Palaeobiology. John Wiley \& Sons.

Harvey, B.C. \& Stewart, A.J. (1991). Fish size and habitat depth relationship in headwater streams. Oecologia 87: 336-342.

Jayaram, K.C. (2010). The freshwater fishes of Indian region. Narendra Publishing House, Delhi, India, 614.

Jha, B.R., (2006). Fish ecological studies and its application in assessing ecological integrity of rivers in Nepal. Abstract-PhD thesis. Human Ecology Alumni Newsletter (HEAR), Vrije Universiteit Brussel.

Kadye, W.T., Magadza, C.H.D., Moyo, N.A.G. \& Kativu, S. (2008). Stream fish assemblages in relation to environmental factors on a montane plateau. Environmental Biology of Fishes, 83: 417-428.

Li, J., Huang, L., Zou, L., Kano, Y., Sato, T. \& Yahara, T. (2012). Spatial and temporal variation of fish assemblages and their association to habitat variables in a mountain stream of North Tiaxi River, China. Environmental Biology of Fishes, 93:403-417.

Limbu, J.H. \& Gupta, S. (2019). Fish diversity of Damak and lower Terai region of Ratuwa River of Jhapa district, Nepal. International Journal of Fauna and Biological studies, 6(1): 1-4.

Limbu, J.H. \& Prasad, A. (2020). Environmental variables and fisheries diversity of the Nuwa River, Panchthar, Nepal. Scientific World, 13: 69-74.

Limbu, J.H., Acharya, G.S. \& Shrestha, O.H. (2018a). A brief report on ichthyofaunal diversity of Dewmai Khola of Ilam district, Nepal. Journal of Natural History Museum, 30: 312-317. 
Limbu, J.H., Baniya, C.B \& Prasad, A. (2019a). Spatiotemporal variation of fish assemblages in Ratuwa River, Ilam, Nepal. Journal of Ecology \& Natural Resources, 3(3): 000168.

Limbu, J.H., Chapagain, N., Gupta, S. \& Sunuwar, S. (2019b). Review on fish diversity of eastern Nepal. International Journal of Fisheries and Aquatic Studies, 7(3): 177-181.

Limbu, J.H., Prasad, A. \& Shrestha, O.H. (2018b). Ichthyofaunal diversity of Bakraha River of Morang district, Nepal. International Journal of Fisheries and Aquatic Studies, 6(5): 267- 271.

Margalef, R. (1968). Perspectives in Ecological Theory. University of Chicago Press, Chicago, IL, 111 p.

Magalhaes, M.F., Batalha, D.C \& Collares-Pereora, M.J. (2002). Gradients in stream fish assemblages across a Mediterranean landscape: contributions of environmental factors and spatial structure. Freshwater Biology 47: 1015-1031.

McGill, B.J., Enquist, B.J., Weiher, E. \& Westoby, M. (2006). Rebuilding community ecology from functional traits. Trends in Ecology and Evolution, 21: $178-185$

Mishra, A.R, \& Baniya, C.B. (2016). Ichthyofaunal diversity and physico-chemical factors of Melamchi River, Sind-upalchok, Nepal. Journal of Institute of Science and Technology, 21(1): 10-18.

Nelson J. (2007). Fishes of the World. Fourth Edition. Hoboken, New Jersey, John Wiley and Sons.

Nepal Electricity Authority/Tanahu Hydropower Limited (2012). NEP: Tanahu (Upper Seti) Hydropower Project. Project Number: 43281-NEP.

Ngor, P.B., Legendre, P., Oberdorff, T. \& Lek, S. (2018). Flow alterations by dams shaped fish assemblage dynamics in the complex Mekong-3S river system. Ecological Indicators, 88: 103-114.

Oksanen, J., Blanchet, F.G., Kindt, R., Legendre, P., Minchin, P.R., O'Hara, R.B., Simpson, G.L., Solymos, P., Stevens, M.H.H. \& Wagner, H. (2015) Vegan: Community Ecology Package. R package version 2: 3-1.

Perry, L. A., Low, P.J., Ellis, J.R. \& Reynolds, J.D. (2005). Climate change and distribution shifts in marine fishes. Science 308(5730): 1912-1915.

Pokharel, K.K. (2011). Study on fish ecology of the Seti Gandaki River Pokhara: II. Spatio-temporal variations in fish communities. Nepal Journal of Science and Technology, 12: 350-357.
Pokharel, K.K., Basnet, K.B., Majupuria, T.C. \& Baniya, C.B. (2018). Correlation between fish assemblage structure and environmental variables of Seti Gandaki River Basin, Nepal. Journal of Freshwater Ecology, 33(1): 31-43.

Punam, G.C. \& Limbu, J.H. (2019). Spatio-temporal variation of fish assemblages in Babai River of Danag district, Province No. 5, Nepal. Our Nature, 17(1): 14-25.

R Core Team. (2018). A language and environment for statistical computing. R Foundation for Statistical Computing, Vienna, Austria. URL https://www.Rproject.org/.

Rao, K.R. (2017). Food and feeding habits of freshwater Catfishes (Siluriformes: Bagridae: Mystus sp.). International Journal of Life-Sciences Scientific Research, 3(1): 786-791.

Rouyer, T., Fromentin, J.M., Me'nard, F., Cazelles, B., Briand, K., Pianet, R., Planque, B. \& Stenseth, N.C. (2008). Complex interplays among population dynamics, environmental forcing, and exploitation in fisheries. Proceedings of the National Academy of Sciences of the United States of America, 105: 54205425 .

Shannon, C.E. \& Weaver, W. (1963) The mathematical theory of communication. Urbana, University of Illinois Press.

Shah, R.B. (2016). Study of the freshwater fish diversity of Koshi River of Nepal. International Journals of Fauna and Biological Studies, 3(4): 78-81.

Shrestha, J., Singh, D.M. \& Saund, T.B. (2009). Fish diversity of Tamor River and its major tributaries of eastern Himalayan region of Nepal. Nepal Journal of Science and Technology, 10: 219-223.

Shrestha, J.N. (2016). Fish diversity of Triyuga River, Udayapur District. Our Nature, 14(1): 124-134.

Subba, B.R., Pokharel, N. \& Pandey, M.R. (2017). Ichthyofaunal diversity of Morang district, Nepal. Our Nature, 15(1,2): 55-67.

Talwar, P.K. \& Jhingran, A.G. (1991). Inland fishes of India and adjacent countries. Oxford and IBH Publishing Co. India, (I, II):1158.

Ter Braak, C.J.F. (1986). Canonical correspondence analysis - a new eigenvector technique for multivariate direct gradient analysis. Ecology, 67(5): 1167-1179

Thapa, B. (2018). Fish diversity of Dipang Lake in the mid hill of Kaski District, Nepal. MSc. Thesis. Central Department of Zoology, Tribhuvan University, Kathmandu, Nepal. 
Yan, Y.H.E., Shan, C.H.U., Ling, X., Xiuying, J.I.A., Anju, T.A.O. \& Yifeng, C. (2010). Spatial and temporal variation of fish assemblages in a subtropical small stream of the Huangshan Mountain. Current Zoology, 56(6): 670-677.
Yu, S.L. \& Lee, T.W. (2002). Habitat preference of the stream fish, Sinogastromyzon puliensis. Zoological Studies, 41: 183-187. 